\title{
A szerzői jog sokoldalúsága - a szabályozás mögött rejlő igények a szerzők és a társadalom oldalán
}

\author{
Sápi Edit \\ egyetemi tanársegéd, Miskolci Egyetem, Civilisztikai Tudományok Intézete, Polgári Jogi Tanszék \\ 3515 Miskolc, Miskolc-Egyetemváros, e-mail: jogsapi@uni-miskolc.hu
}

\begin{abstract}
Absztrakt
A kutatás alapvetö célja annak vizsgálata, hogy az innováció és a társadalmi innováció milyen kapcsolatban állnak a szerzői jogi szabályrendszer kialakulásával és jogfejlödésével. A szerzöi jogi szabályanyag megalkotásának különbözö társadalmi és gazdasági okai voltak és a jogterület folyamatos fejlödésén és dinamizmusán egyaránt érezhetö a mögöttes társadalmi igények láncolata. A tanulmányban azt vázoljuk fel, hogy mik azok a garanciális jelleg szabályok, amelyek ösztönzik a szellemi alkotások létrehozását, illetve melyek azok a korlátozó szabályok, amelyek a társadalom igényeit helyezik elötérbe a szerzö jogaival szemben.
\end{abstract}

Kulcsszavak: társadalmi innováció, szerzői jog, szerzöt megilletö jogok, személyhez füzödö jogok, szabad felhasználás

\begin{abstract}
The basic aim of the research is to examine how innovation and social innovation are related to the formation and development of the rules of copyright law. There were various social and economic reasons for the creation of copyright law, and the chain of underlying social needs can be felt in the continuous development and dynamism of the field of law. In this study, I outline the rules of the guarantee nature of rules which encourage the creation of intellectual creations and the restrictive rules which prioritize the needs of society over the rights of the author.
\end{abstract}

Keywords: social innovation, copyright law, author's right, moral rights, free use

\section{Bevezető gondolatok}

A szellemi alkotások jogának hagyományosan mindkét nagy területe - a szerzői jog és az iparjogvédelem is - több szempontból is értékteremtő. Míg az iparjogvédelem a müszaki jellegü szellemi alkotások $^{1}$, valamint a vállalat- és árujelzők ${ }^{2}$ jogi oltalmával foglalkozik, addig a szerzői jog sokkal inkább a kulturális, müvészeti és tudományos eredmények jogi védelmét tartja szem előtt. Mindkét terület a tág értelemben vett polgári joghoz tartozik, annak viszonylagosan önálló területe. Mindkét terület igen jelentőst hatást gyakorol az emberiségre, mind gazdasági, mind társadalmi, kulturális és innovatív szempontból.

A szellemi alkotásokra vonatkozó jogi szabályozás célja a kultúra megőrzése és a szellemi termékek gazdasági kiaknázása azáltal, hogy ösztönzi is a szellemi termékek létrehozatalát. Ezt a célt az egyes vonatkozó jogszabályok preambulumai kifejezésre is juttatják. Például a találmányok szabadal-

\footnotetext{
${ }^{1}$ E körbe sorolható a találmányok szabadalmi oltalma, a használati minta oltalma, a topográfiaoltalom, valamint a formatervezési minta oltalma.

${ }^{2} \mathrm{E}$ fogalom alá tartozik a védjegy, valamint a földrajzi árujelzők (földrajzi jelzés és eredetmegjelölés).
} 
mi oltalmáról szóló törvény ${ }^{3}$ a hangsúlyt a müszaki, gazdasági fejlődésre helyezi, amikor úgy fogalmaz, hogy „A magyar nemzetgazdaság müszaki fejlödésének, a korszerü technika meghonositásának, valamint a feltalálók erkölcsi és anyagi elismerésének elömozditása érdekében (...)”. A védjegyekröl és földrajzi árujelzőkről szóló törvény ${ }^{4}$ szabályait „, A magyar piacgazdaság fejlődésének elömozditása, a megkülönböztetésre alkalmas árujelzök használatán alapuló verseny feltételeinek javitása, a fogyasztók tájékozódásának elösegitése érdekében" alkotta a jogalkotó. A szerzői jogról szóló törvény ${ }^{5}$ preambuluma szerint pedig „A technikai fejlödéssel lépést tartó, korszerü szerzői jogi szabályozás meghatározó szerepet tölt be a szellemi alkotás ösztönzésében, a nemzeti és az egyetemes kultúra értékeinek megóvásában; egyensúlyt teremt és tart fenn a szerzök és más jogosultak, valamint a felhasználók és a széles közönség érdekei között, tekintettel az oktatás, a müvelödés, a tudományos kutatás és a szabad információhoz jutás igényeire is; gondoskodik továbbá a szerzői jog és a kapcsolódó jogok széles körü, hatékony érvényesüléséröl."

Az alkotómunkát és az alkotó embert védő szerzői jog egyik nem titkolt célja tehát, hogy a szerzői művek megszületését és az azt létrehozó alkotó munkát ösztönözze, a nemzeti és egyetemes kultúrát megőrizze, így végső soron elősegítve annak terjedését is. E cél megjelenik a szerzői jogi szabályozásban is, hiszen a szabályanyag arra törekszik, hogy a szerzők, a felhasználók és a társadalom igényeit is kiegyenlítse, megfelelően biztosítva a szerzők számára a védelmi, garanciális funkciót, valamint a társadalom és a felhasználók számára az információ áramlást, valamint a kulturális és müvészeti alkotásokhoz a szabad(abb) hozzájutást.

\section{A szerzői jog kialakulásának okai és a jogfejlődés vázlata}

Régóta vitathatatlan tény, hogy a szerzői jogi védelem kialakulásában és térnyerésében meghatározó szerep jut és jutott is mindig a müszaki megoldásoknak, technikai fejlődésnek. ${ }^{6}$ Ha végigtekintünk a szerzői jogon, látható, hogy a társadalmi, kulturális, gazdasági problémákra, kihívásokra milyen módon, milyen megoldásokkal válaszolt a jogalkotó. Valójában annak megítélése, hogy milyen jogi megoldás minősül innovatívnak, nézőpont kérdése. A nézőpontot pedig nagyban alakítja az adott kor és annak társadalmi berendezkedése, gazdasági helyzete. Önmagában a szerzői jogi védelemnek a megjelenése anno újszerü - ma azt mondhatnánk társadalmi innovációt elősegítő - megoldás volt és abban az időben már igencsak égető kérdésre adott válasz volt. A szerzői jogi oltalom kialakulása több okra vezethető vissza, melyek közül a jogirodalom által legföbb oknak elismert tényező a könyvnyomtatás feltalálása volt. ${ }^{7}$ A törvényi szintủ szabályozás elsőként Angliában, Anna királynő uralkodásának idején jelent meg, amikor 1709-ben kiadta Statutumát, amely 1710. április 10-én lépett hatályba. A Statute of Anne valójában egy elidegenithetö copyright-ot teremtett és a szerzők mellett a kiadók, mint jog-

\footnotetext{
3 1995. évi XXXIII. törvény a találmányok szabadalmi oltalmáról

${ }^{4}$ 1997. évi XI. törvény a védjegyek és a földrajzi árujelzők oltalmáról

5 1999. évi LXXVI. törvény a szerzői jogról (a továbbiakban: Szjt.)

${ }^{6}$ Grad-Gyenge, A.: A modern technológiák szerzői jogi és iparjogvédelmi kihívásai - különös tekintettel a fájlcserére, a felhö-programozásra és a 3D nyomtatókra: File-sharing, cloud computing and 3D printing actual technological challenges in the field of copyright. In: Tóth, A. (szerk.): Új globális technológiák jogi kihívásai, Patrocinium Kiadó, Budapest, 2016, 99.

${ }^{7}$ A szerzői jog kialakulásával, az azt szorgalmazó igényekkel foglalkozó irodalmak közül - a teljesség igénye nélkül - lásd pl.: BOYTHA, Gy.: Whose Right is Copyright? In: Beier, F.: (szerk.): Festschrift für Eugen Ulmer zum 80. Geburtstag, GRUR, Int. 1983. 379-385.; Mezei, P.: A szerzői jog története a törvényi szabályozásig (1884: XVI. tc.), Jogelméleti Szemle, 2004/3. sz., Legeza, D.: „Egyszer mindenkorra és örökáron” a szerzői jog és forgalomképessége Magyarországon a reformkortól 1952-ig. (PhD értekezés), Szeged, 2017.
} 
utódok védelmét célozta. A „nemzetközi jogvédelem” első lépései az 1840-es években megkötött bilaterális egyezmények voltak, amelyeken keresztül két ország rendezte az egymás közötti, szerzői jogi jogviszonyait. Az első többoldalú szerzői jogi nemzetközi egyezmény, az 1886-ban elfogadott Berni Uniós Egyezmény ${ }^{8}$ volt. Hazai viszonylatban 1884-ben született meg az első szerzői jogi törvény, ${ }^{9}$ ugyanakkor hazánkban a jogi szabályozás első lépéseként az 1844. évi Szemere Bertalan-féle törvényjavaslatot tartják számon, amely azonban az elmaradt királyi szentesítés miatt nem emelkedett törvényerőre. A fentebb már említett első szerzői jogi törvény Arany László kezdeményezésére és Apáthy István elöterjesztése nyomán született meg, német mintára. Az első jogszabály megalkotásakor a jogalkotói cél természetesen az volt, hogy a jogi védelem alapjait lefektesse, annak kereteit meghatározza. A következő szerzői jogi törvény, az 1921. évi LIV. törvénycikk felépítésében nagyban követte elödjét, hiszen annak újrakodifikálásaként született meg. Ennek fontos mozgatórugója a Berni Unióhoz való csatlakozás volt. Harmadik szerzői jogi törvényünket, az 1969. évi III. törvényt elsősorban a társadalmi és állami berendezkedés gyökeres változásai hívták életre, mely szempontokra a törvény indokolása is kitért. ${ }^{10}$ Kijelenthetjük, hogy a jelenleg hatályban lévő szerzői jogi törvényünk ${ }^{11} \mathrm{az}$, amelyik a leginkább dinamikus életet éli, hiszen azok a jellegzetességek - pl. a territorialitás, vagy a müszaki fejlődés, a digitalizáció komoly hatásai -, melyek mindig komoly szerepet játszottak a szerzői jogi szabályozás életében, az utóbbi években még inkább felerősödtek.

\section{A személyhez füződő jogok garanciális jellege}

Valójában a személyhez füződő jogok deklarálása és hangsúlyozása az a politika, amellyel a szerzői jog szabályrendszere a leghatékonyabban fel tud lépni az alkotómunka ösztönzése érdekében. Ezt a tényt már Apáthy István is hangsúlyozta, amikor úgy fogalmazott, hogy „Az anyagi haszon azonban, melyet az alktoás a szerzönek biztosit és biztositani hivatva van, nem egyedüli rugója tevékenységének; ahhoz ideális czélok is füzödnek, melyeknek megvalósitása a legtöbb esetben, sokkal fontosabb az anyagiaknál. A szellemi munkás hírre, dicsöségre törekszik; nevének a tudomány, vagy a müvészet történetében maradandó helyet és alkotásaiban emléket kiván biztositani, mely nevét századokon át hirdeti és részére a késö utókor csodálatát és háláját fentartja." "12

A szerzői jog már pusztán alapvető feladatával, vagyis a jogi oltalom biztosításával elősegíti az értékteremtést is. Az alkotómunkát a jogi szabályozás pedig akkor tudja igazán elősegítenni, ösztönözni, ha az alkotó tudja, hogy tevékenységét elismerik, legalább az erkölcsi védelem szintjén. Ez a védelem pedig nagyban megmutatkozik a személyhez füződő jogok garantálásán keresztül.

A szerzői személyhez füződő jogok között a jogalktó a név feltüntetésének jogát, a mü nyilvánosságra hozatalának jogát, valamint a mü egységének védelmét nevesíti. ${ }^{13}$ A mü és alkotója közötti legszorosabb kapcsolatot a leglátványosabban a név feltüntetésének joga fejezi ki, hiszen eszerint a szerző nevét minden esetben fel kell tüntetni a müvön és annak átdolgozásán, feldolgozásán is, függetlenül a védelmi idő leteltétől. Ugyanakkor a szerző és müve közötti szellemi egységet az integritáshoz füződő jog helyezi leginkább védelem alá. Jelenleg hatályos szerzői jogi törvényünk 13.

\footnotetext{
${ }^{8}$ Az irodalmi és müvészeti müvek védelméröl szóló Berni Egyezmény. (1886. szeptember 9.; hatályba lépés időpontja: 1887. december 4. Magyarországon kihirdette az 1975. évi 4. törvényerejü rendelet.)

9 1884. évi XVI. törvénycikk a szerzői jogról

${ }^{10} \mathrm{Az}$ 1969. évi III. törvény indokolása. Általános indokolás.

${ }^{11}$ A szerzői jogról szóló 1999. évi LXXVI. törvény (a továbbiakban: Szjt.)

12 Apáthy, I.: A szerzői jogról szóló törvény (1884. XVI. t.cz.) méltatása jogi és gazdasági szempontból, (székfoglaló értekezés) Budapest, 1885. 5.

${ }^{13}$ Szjt. 10-13.§
} 
$\S$-a e jog tekintetében úgy szól, hogy „A szerző személyhez füzödö jogát sérti müvének mindenfajta eltorzitása, megcsonkítása, vagy a mü más olyan megváltoztatása vagy a müvel kapcsolatos más olyan visszaélés, amely a szerzö becsületére vagy hírnevére sérelmes. " Az integritáshoz füződő jog a mü és a szerző közötti szoros erkölcsi kapcsolatot fejezi ki, így érthető a jogi norma alapvető rendeltetése is: a szerző müve torzításoktól, jóhírnevet és becsületet sértő változtatásoktól mentesen kerüljön a közönség elé. Az integritási szabály létjogosultága az, hogy a szerzőt a művei alapján ítéli meg mind a társadalom, mind pedig a szakma, így tehát az egyik legszentebb joga, hogy a müve úgy kerüljön a nyilvánosság elé, ahogyan ő azt megalkotta. E jog komplexitása mellett nagyon lényeges, hogy minden mütípus esetében specialitásokat mutat, hiszen különbözö értelmezés szükséges egy építőmüvészeti alkotás, ${ }^{14}$ egy film ${ }^{15}$, egy színpadi mü ${ }^{16}$ vagy például egy digitális müpéldány ${ }^{17}$ esetében. ${ }^{18}$

\section{A korlátozás igénye}

A szerzői jog kizárólagos jogot biztosít a jogosult számára atekintetben, hogy művének felhasználását engedélyezze. Így látható, hogy a védelem középpontjában a szerző helyezkedik el, ugyanakkor ez a védelem mégsem jelent korlátlanságot. A szerzői jogi kivételek és korlátozások, a szabad felhasználás szabályai a szerzői jog örökérvényü témakörei közé tartozik. Ennek oka, hogy a szerzői jogi kivételek és korlátozások igazodnak az adott kor társadalmi, gazdasági, jogpolitikai sajátosságaihoz és bizonyos érdekekhez. Figyelembe véve napjainkat, amikor az internet, a robotika, a mesterséges intelligencia egyre nagyobb teret nyer magának, azt lehet mondani, hogy ez az egyensúly, amit ideálisnak tartanánk, talán sosem fog létezni.

A viszonyrendszer és a hagyományos szerzői jogi szerepek átrendeződése természetesen érinti a szerzői jogi kivételek és korlátozások rendszerét is. A viszonyrendszer bomlása és átalakulása a DSM irányelv ${ }^{19}$ szellemében is megfigyelhetö, melynek preambulumában rögzített célja, hogy a kivételek és korlátozások biztosításán keresztül méltányos egyensúlyt teremtsen (és tartson fenn) egyrészről a szerzők és más jogosultak, másrészről pedig a felhasználók jogai és érdekei között, beleértve az internetes platformokat is.

A leggyakoribb szabad felhasználások körébe az ún. magáncélú felhasználások sorolhatóak, így például a magáncélú másolás vagy az idézés. Annak ellenére, hogy az idézés az egyik leggyakrabban előforduló szabad felhasználási esetkör, a szerzői jog által védett tartalmakhoz való könnyebb hozzáférését önmagában még nem jelenti. Ugyanígy nem jelenti önmagában a tartalomhoz való szabad hozzáférés biztosítását az átvétel ${ }^{20}$ sem, hiszen nem ebben rejlik az eredendő céljuk. Átvétel esetén a szem-

\footnotetext{
${ }^{14}$ Barta, J.: A tervezői tevékenység komplex bemutatása, valamint az épitészeti, müszaki alkotások és tervek szerzői jogvédelme, Patrocinium Kiadó, Budapest, 2018.

${ }^{15}$ Grad-Gyenge, A.: Film és szerzői jog. A megfilmesitési szerződés. Médiatudományi Intézet, 2016, 72-74.

${ }^{16}$ Sápi, E.: A színpadi müvek szerzói joga, Patrocinium Kiadó, Budapest, 2019, 151-158.

17 Pogácsás, A.: A digitális mü integritásvédelmének aktuális kérdései, In: Grad-Gyenge, A., Kabai, E., Menyhárd, A. (szerk.): Liber Amicorum. Studia G. Faludi Dedicata. Ünnepi tanulmányok Faludi Gábor 65. születésnapja tiszteletére, ELTE, Állam-és Jogtudományi Kar, Budapest, 2018,

${ }^{18}$ A különbözőségek megjelenéséről lásd: Sápi, E.: Mennyire egységes a mü egységének védelme? Miskolci Jogi Szemle, 2020/1. 169-182.

${ }^{19}$ Az Európai Parlament és a Tanács (EU) 2019/790 irányelve (2019. április 17.) a digitális egységes piacon a szerzői és szomszédos jogokról, valamint a 96/9/EK és a 2001/29/EK irányelv módosításáról (a továbbiakban: DSM irányelv)

${ }^{20}$ Szjt. 34. § (2) bek.
} 
léltetésben, idézés esetén pedig a tudományos kutatás fellendítésében, annak elősegítésében gyökerezik a korlátozás.

Már közelebbi kapcsolódó pontot jelent a tartalmakhoz való szabad hozzáféréssel a magáncélú másolás. Ez a szabad felhasználás az iskolai, oktatási cél és az információhoz jutás miatt korlátozza a szerzői jogot, így az alapvető elképzelés és igény érthető is indokolható. Szintén a hozzáférés elősegítését jelenti az országos szakkönyvtárak által a müpéldányok haszonkölcsönbe adása,${ }^{21}$ melynek oka a jogszabályi indokolás szerint, hogy az országos szakkönyvtárak - mint egyedüli jogosulti kör - olyan kiemelkedő kulturális, tudományos jelentőségü gyüjtemények, amelyek esetében különösen indokolt a hozzáférés szabad felhasználással való segítése.

Nemzetközi ${ }^{22}$ és európai uniós ${ }^{23}$ kötelezettség átültetésének nyomán szabad felhasználást biztosít a hazai szerzői jog a vakok és gyengénlátók számára is. A szerzői jog ilyen célú korlátozásának oka, hogy a vakok és látássérültek ugyanolyan mértékben jogosultak a mủvekhez való hozzáférésre, az információhoz, kultúrához és a tudomány vívmányaihoz való hozzáférésre és azok megismerésére, mint azok, akik nem szenvednek látáskárosodásban. Lényegi vonása a vonatkozó szabályoknak, hogy szerzői jogi kivételeket és korlátozásokat vezet be, így a müveket elérhetővé teszi a látássérült vagy a nyomtatott szöveget más okból olvasni képtelen személyek számára, ez pedig a szerzői jog és a fogyatékossággal élő személyek jogai közötti egyensúly megteremtésére való törekvést mutatja. Mindezek alapján külön szabad felhasználási szabályokat határoz meg az Szjt. is azon személyek javára, akik fogyatékossággal élnek. ${ }^{24}$

A 2020-as évben fejét felütő pandémia a szerzői jogi szabályozást sem hagyta érintetlenül, hiszen az oktatás és tudományos kutatás elnehezülése miatt lazítani, változtatni kellett a szabad felhasználási szabályanyagon. Ennek következtében bővül az oktatási célú szabad felhasználások szabályaa ${ }^{25}$, különösen a lehívásra történő hozzáférhetővé tétel tekintetében és így a jogszabály értelmében a könyvként kiadott mü egyes részei, valamint újság- és folyóiratcikkek az iskolai oktatás céljára egy-egy csoport vagy iskolai osztály létszámának megfelelő, valamint a köznevelés, a szakképzés, illetve a felsőoktatás keretében szervezett vizsgákhoz szükséges példányszámban többszörözhetők, az érintett tanulók, hallgatók részére terjeszthetők és az oktatási intézmény biztonságos elektronikus hálózatán keresztül szemléltetés érdekében számukra lehívásra hozzáférhetővé tehetők. A jogalkotó ezen gyors reakciójával lehetővé vált, hogy a távoktatáshoz szükséges feltételek - a korábbi állapothoz képest - szerzöi jogi szempontból is letisztultabban valósulhassanak meg.

\section{Záró gondolatok}

Több, mint tizenöt évvel ezelőtt írta azt Bobrovszky Jenö, hogy „A nagy dilemma tehát abban foglalható össze, hogy hogyan biztositható a jog legföbb erénye, az egyensúly a szellemi tulajdon Bábel

\footnotetext{
${ }^{21}$ Szjt. 39. §

${ }^{22}$ United Nations Convention on the Rights of Persons with Disabilities (UNCRPD) és Optional Protocol to the Convention on the Rights of Persons with Disabilities valamint Marrakesh Treaty to Facilitate Access to Published Works for Persons Who Are Blind, Visually Impaired, or Otherwise Print Disabled

${ }^{23}$ Az Európai Parlament és a Tanács (EU) 2017/1564 irányelve és Az Európai Parlament és a Tanács (EU) 2017/1563 rendelete

${ }^{24}$ Szjt. $41 . \S$

${ }^{25}$ Szjt. 35. § (5) bek.
} 


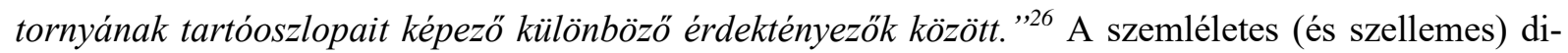
lemma mögött - ahogyan azt az idézett szerző munkájában bemutatta - meghúzódó tartalom már akkor abba az irányba hatott, hogy a jogszabályi preambulumok által deklarált egyensúly tényleges megteremtése és érvényesülése meglehetősen billegős.

A szerző oldalán megjelenő erős személyhez füződő jogok és kizárólagos vagyoni jogok hivatottak garantálni az ő érdekeinek védelmét. Természetesen e szabályok létezése önmagában még nem biztosítja a szerző jogainak sérthetetlenségét, azonban törekednek a megfelelő védelem irányába.

A szerzői jogi kivételeknek és korlátozásoknak valójában bizonyos társadalmi érdekek, igények kielégítését kell(ene) szolgálniuk. A jogintézmény alapvető rendeltetése, okai valamint az azok hátterében meghúzódó érdekek teljességgel érthetőek, támogatandóak és fontosak a szerzői jog rendszerében. Ugyanakkor a szabályozásban néhol felfedezhetőek hiányosságok, vagy éppen túlzott szigorítások, melyek olyannyira elnehezítik a szabad felhasználások jogszerủ gyakorlását, hogy a felhasználás - sok esetben még ha akaratlanul is, de - átbillen az engedélyt nélkülöző, nem megengedett felhasználások terébe. Különösen igaz ez akkor, amikor a digitalizáció és a digitális technikák is elősegítik a művekhez való hozzáférést. ${ }^{27}$ Emiatt arra is figyelemmel kell lenni, hogy ezek a felhasználások jogszerü módon történjenek, a jogalkotó által lehetővé tett kivételek és korlátozások útján, ne pedig a kalóz vizekre evezve. Ehhez a jogkövető magatartáshoz viszont egyrészt szükség van arra, hogy világos, egyértelmü és betartható feltételeket lássanak a felhasználók, a szerzők pedig szerzői jog-tudatosabban lássák alkotómunkájuk folyamatát és eredményét.

\section{Köszönetnyilvánítás}

A cikkben ismertetett kutató munka az EFOP-3.6.1-16-2016-00011 jelü „Fiatalodó és Megújuló Egyetem - Innovatív Tudásváros - a Miskolci Egyetem intelligens szakosodást szolgáló intézményi fejlesztése" projekt részeként - a Széchenyi 2020 keretében - az Európai Unió támogatásával, az Európai Szociális Alap társfinanszírozásával valósul meg.

\section{Irodalom}

[1] Apáthy, I.: A szerzői jogról szóló törvény (1884. XVI. t.cz.) méltatása jogi és gazdasági szempontból, (székfoglaló értekezés) Budapest, 1885.

[2] Barta, J.: A tervezöi tevékenység komplex bemutatása, valamint az épitészeti, müszaki alkotások és tervek szerzői jogvédelme, Patrocinium Kiadó, Budapest, 2018.

[3] Bobrovszky, J.: A szellemi tulajdon néhány dilemmájáról a körte és a sajt között, In: Király, M., Gyertyánfy, P. (szerk.): Liber Amicorum, Studia Gy Boytha Dedicata, ELTE ÁJK Polgári Jogi Tanszék, Nemzetközi Magán Jogi és Európai Gazdasági Jogi Tanszék, Budapest, 2004.

[4] Boytha, Gy.: Whose Right is Copyright? In: Beier, F.: (szerk.): Festschrift für Eugen Ulmer zum 80. Geburtstag, GRUR, Int. (1983) pp. 379-385.

[5] Grad-Gyenge, A.: A modern technológiák szerzöi jogi és iparjogvédelmi kihivásai - különös tekintettel a fájlcserére, a felhö-programozásra és a 3D nyomtatókra: File-sharing, cloud computing and 3D printing - actual technological challenges in the field of copyright, In: Tóth, A. (szerk.): Új globális technológiák jogi kihívásai, Patrocinium Kiadó, Budapest, 2016.

\footnotetext{
${ }^{26}$ Bobrovszky, J.: A szellemi tulajdon néhány dilemmájáról a körte és a sajt között, In: Király, M., Gyertyánfy, P. (szerk.): Liber Amicorum, Studia Gy Boytha Dedicata, ELTE ÁJK Polgári Jogi Tanszék, Nemzetközi Magán jogi és Európai Gazdasági Jogi Tanszék, Budapest, 2004, 35.

${ }^{27}$ Pogácsás, A.: Tartalomáramlás és hozzáférés a szerzői jog „fogyasztói korszakában”, In Medias Res, $2017 / 1$.
} 162. 
[6] Grad-Gyenge, A.: Film és szerzői jog, A megfilmesitési szerződés, Médiatudományi Intézet, 2016.

[7] Legeza, D.: „Egyszer mindenkorra és örökáron” a szerzői jog és forgalomképessége Magyarországon a reformkortól 1952-ig, (PhD értekezés), Szeged, 2017.

[8] Mezei, P.: A szerzői jog története a törvényi szabályozásig (1884: XVI. tc.), Jogelméleti Szemle, 2004/3. sz.

[9] Pogácsás, A.: A digitális mü integritásvédelmének aktuális kérdése, In: Grad-Gyenge, A., Kabai, E., Menyhárd, A. (szerk.): Liber Amicorum. Studia G. Faludi Dedicata. Ünnepi tanulmányok Faludi Gábor 65. születésnapja tiszteletére, ELTE, Állam-és Jogtudományi Kar, Budapest, 2018.

[10] Pogácsás, A: Tartalomáramlás és hozzáférés a szerzői jog „fogyasztói korszakában”, In Medias Res, 2017/1.

[11] Sápi, E.: A színpadi müvek szerzöi joga, Patrocinium Kiadó, Budapest, 2019.

[12] Sápi, E.: Mennyire egységes a mü egységének védelme? Miskolci Jogi Szemle, 2020/1. 